\title{
Diagnostic Approach of Abnormal Uterine Bleeding
}

\section{Pendekatan Diagnostik Perdarahan Uterus Abnormal}

\author{
Riyan H. Kurniawan, St. Finekri A. Abidin \\ Department of Obstetrics and Gynecology \\ Faculty of Medicine University of Indonesia/ \\ Gatot Soebroto Central Army Hospital \\ Jakarta
}

\begin{abstract}
Objective: To introduce and apply PALM-COEIN classification system as standard diagnostic approach of AUB to investigate the etiology.

Method: Three cases will be discussed. First, Mrs, 45 yo, P3 with AUB due to suspected adenomiosis, performed total hysterectomy with histopathology result leiomyoma. Second case. Mrs, 43 yo, $\mathrm{P}_{3}$ with AUB due to suspected adenomiosis, performed total hysterectomy with histopathology result adenomyoma. Third case, Mrs, 48 yo, $\mathrm{P}_{3}$ with AUB due to suspected adenomiosis, performed total hysterectomy and bilateral salpingoophorectomy with PA result adenomyosis.

Result: AUB diagnostic approach with PALM-COEIN performed to look for etiology and prevent mistake of etiology of AUB, such as cancer that must be consider on AUB patient above 40 years old.

Conclusion: This PALM-COEIN classification should become standard diagnostic approach to investigate the etiology.

[Indones J Obstet Gynecol 2014; 2: 106-109]

Keywords: abnormal uterine bleeding.
\end{abstract}

Abstrak

Tujuan: Diketahui dan diaplikasikannya sistem klasifikasi PALMCOEIN sebagai standar pendekatan diagnosis PUA dalam mencari etiologi.

Metode: Tiga kasus yang akan dibahas sebagai bahan diskusi pendekatan diagnosis PUA yang dilakukan. Kasus pertama Ny, 45 tahun $P_{3}$ dengan PUA ecsuspek adenomiosis, dilakukan histerektomi total dengan hasil patologi anatomi (PA) leiomioma. Kasus kedua Ny, 43 tahun, $P_{3}$ dengan PUA ecsuspek adenomiosis, dilakukan histerektomi total dengan hasil PA adenomioma. Kasus ketiga Ny, 48 tahun, $P_{3}$ dengan PUA ecsuspek adenomiosis, dilakukan histerektomi total dan salpingooforektomi bilateral dengan hasil PA adenomiosis.

Hasil: Pendekatan diagnosis PUA melalui PALM-COEIN dilakukan untuk mencari etiologi dan mencegah kesalahan diagnosis lain sebagai etiologi PUA, misalnya keganasan yang harus dipikirkan pada PUA pasien berusia 40 tahun ke atas.

Kesimpulan: Sistem klasifikasi PALM-COEIN ini sebaiknya menjadi dasar pola pendekatan diagnosis perdarahan uterus abnormal agar diketahui etiologinya.

[Maj Obstet Ginekol Indones 2014; 2: 106-109]

Kata kunci: perdarahan uterus abnormal.

Correspondence: Riyan H. Kurniawan, Department of Obstetrics and Gynecology, Faculty of Medicine University of Indonesia/ Gatot Soebroto Central Army Hospital, Jakarta. Mobile phone: 08128195884, email: riyanharikurniawan@yahoo.com

\section{INTRODUCTION}

Abnormal uterine bleeding (AUB) is the most common chief complaint from patients that come to the gynecologist. According to the data from gynecology clinic of Gatot Soebroto Central Army Hospital, the number of patient's complaining of AUB was 87 from the total of 490 patients $(17.5 \%)$ from January $1^{\text {st }} 2013$ until March $31^{\text {st }} 2013$. Almost $80 \%$ is perimenopause and post-menopause patient, women above 40 years old. Considering high rate of AUB patient, guideline to manage this symptom is required, especially in the gynecology policlinic.
Based on PALM-COEIN classification for Causes of Abnormal Uterine Bleeding developed by the FIGO Menstrual Disorders Group (FMDG) ${ }^{1}$, etiology of AUB can be stratified into nine basic categories according to the acronym PALM-COEIN: Polyp, Adenomyosis, Leiomyoma, Malignancy and hyperplasia, Coagulopathy, Ovulatory Disorders, Endometrium, Iatrogenic, and Not Classified ${ }^{1}$ (Figure 1). PALM group are discrete (structural) entities that are measureable visually, by use imaging techniques, and/or by use of histopathology while the COEIN group is related to entities that are not defined by imaging or histopathology (nonstructural). 

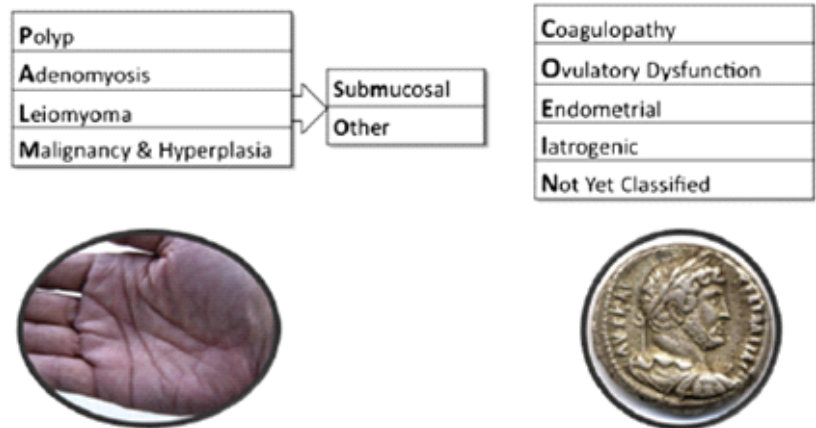

Figure 1. Munro. FIGO Classification System for Causes of AUB Fertil Steril 2011.

AUB at perimenopause or postmenopause usually happens because of structural abnormality, such as polyp, adenomyosis, leiomyoma, malignancy such as cervical cancer, endometrial cancer or endometrial hyperplasia. The most important in diagnostic approach of AUB at this age area is excluding malignancy. One of supporting examination by doing curettage, endometrial biopsy until hysteroscopy.

This article is discussing a case series AUB patient which undergone laparotomy hysterectomy and the histopathology result of specimen as a golden standard of diagnostic tools. The objective is to introduce and apply PALM-COEIN classification system as standard diagnostic approach of AUB to investigate the etiology.

\section{METHODS}

Three cases will be discussed. The first case was a female patient, married, 45 years old, with history of 3 parities complaining of AUB due to suspected adenomyosis. She still had regular menstruation. No history of diabetes mellitus or hypertension. No obesity. Normal papsmear. Uterus was palpated and felt enlarged until two fingers above navel. Ultrasonography (USG) shows hypo-hyperechoic mass at uterus without clear border sizes $13 \times 12$ $\mathrm{cm}$ corresponding to the diagnosis of adenomyosis (Figure 2). A total hysterectomy was then performed (Figure 3). Histopathology result revealed multiple leiomyoma.

Second case. Mrs, 43 yo, parity 3 with AUB due to suspected adenomyosis. Still got periods. No history of diabetes mellitus or hypertension. No obesity. Normal papsmear. Uterus palpated enlarged until 3 fingers above simphysis. USG shows mass without clear border in myometrium correspond to adenomyosis. Patient was performed laparotomy total hysterectomy (Figure 4). Histopathology result is adenomyoma.

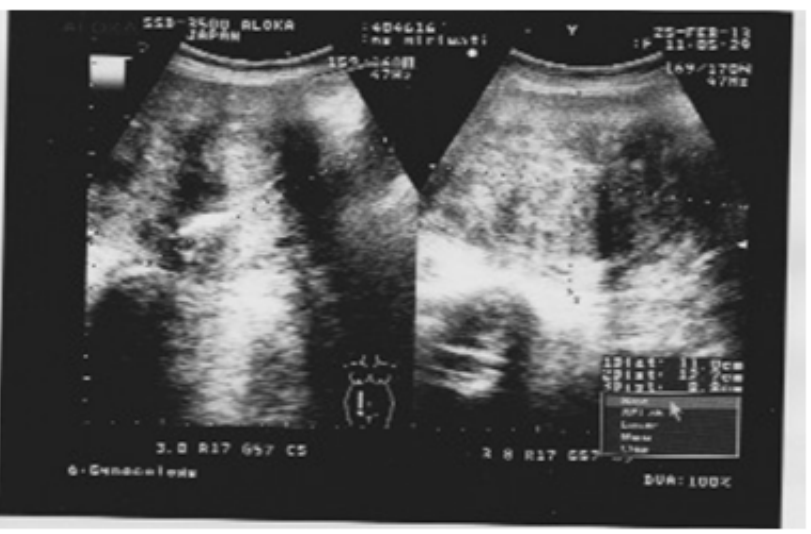

Figure 2. USG shows mass without clear border in myometrium.

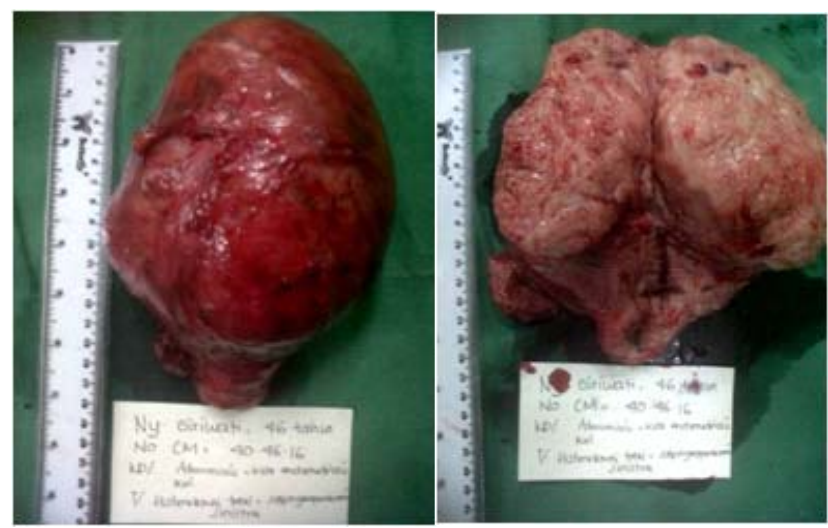

Figure 3. Uterus enlarged size $12 \times 13 \mathrm{~cm}$ (left), and mass in anterior corpus without clear border.

Third case, Mrs, 48 yo, P3 with AUB due to suspected adenomyosis. No more regular period since 2 years before. No diabetes mellitus or hypertension. No obesity. Uterus palpated a bit enlarged. Normal papsmear. USG showed an image consistent with myoma in the corpus (Figure 5). Total hysterectomy and bilateral salpingooophorectomy 
(Figure 6) was then performed. Histopathology result showed adenomyosis.

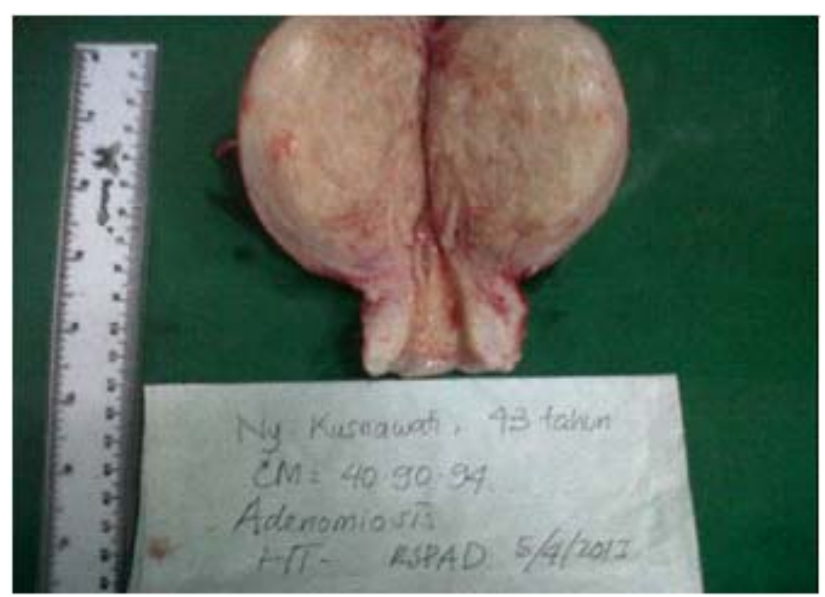

Figure 4. Uterus with thickening myometrium without clear borded correspond to adenomyosis

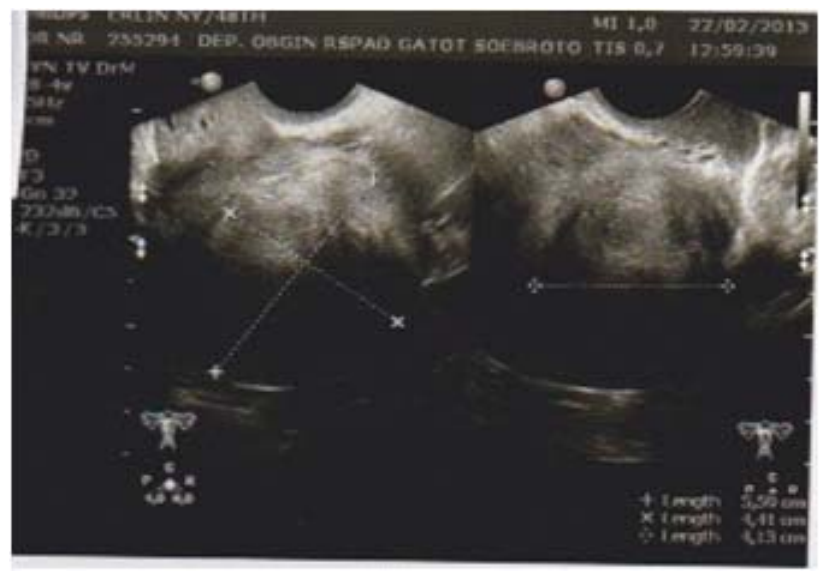

Figure 5. Mass with clear border at anterior corpus correspond to leiomyoma.

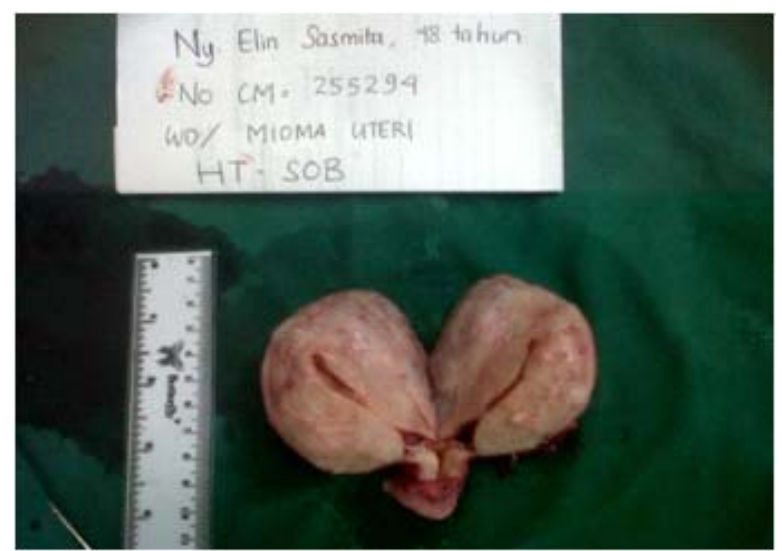

Figure 6. Uterus enlarged size $10 \times 6 \mathrm{~cm}$ with hard palpated correspond to adenomyosis.

\section{DISCUSSION}

AUB diagnostic approach with PALM-COEIN was performed to look for etiology and prevent mistake of etiology of AUB, such as cancer, which must be considered on AUB patient above 40 years old. Inspection of cervix and pap-smear examination is a must. Need to do screening patient with high risk of endometrial cancer such as obesity patient with body weight more than $90 \mathrm{~kg}$, diabetes mellitus or chronic hypertension.

Patient with high risk of endometrial cancer better had a curettage, endometrial biopsy or hysteroscopy to exclude possibility of malignancy. Other alternative diagnostic tool is transvaginal sonography, with or without saline-infusion.

On the first case, physical and supporting examination shows leiomyoma. Based on PALM-COEIN classification, leiomyoma is one of the AUB cause. Pathology result showed that it was leiomyoma. On the second case, physical and supporting examination was consistent with adenomyosis, which also one of the AUB cause based on PALM-COEIN. Pathology examination confirmed that it was adenomyosis. Similar like second case, the third case showed that AUB was caused by adenomyosis. The pathology result was consistent with adenomyosis.

From the three cases above, we can learn as examples how diagnostic approach to find etiology of AUB was performed. It is consisted of history taking, physical examination, and supporting examination (USG, papsmear, and histopathology). Abnormality of nonstructural etiology can be suspected by history taking. For example, approximately $90 \%$ of patients with coagulopathy abnormalities can be suspected by structural history taking for coagulopathies (AUB-C). ${ }^{2}$

Atypical hyperplasia and malignancy are important potential causes associated with AUB. This diagnosis must be considered in any woman with predisposing factors such as obesity or a history of chronic anovulation. ${ }^{3,4}$ Procedure of endometrial sampling is better performed to exclude endometrial malignancy.

\section{CONCLUSION}

This PALM-COEIN classification should become standard diagnostic approach to investigate the etiology of AUB. 


\section{REFERENCES}

1. Munro MG, Crithley HO, Broder MS, Fraser IS. FIGO Working Group on Menstrual Disorders, FIGO classification system (PALM-COEIN) for causes of abnormal uterine bleeding in non gravid women of reproductive age. Int J Gynecol Obstet 2011; 113: 3-13.

2. Kadir RA, Economides DL, Sabin CA, Owens D, Lee CA. Frequency of inherited bleeding disorders in women with menorrhagia. Lancet 1998; 351: 485-9.
3. Tavassoli FA, Devilee P. World Health Organization classification of tumors: pathology and genetics of tumours of the breast and female genital organs. Lyon, France: IARC Press; 2003.

4. Creasman WT, Odicino F, Maisonneuve P, Quinn MA, Beller $\mathrm{U}$, Benedet JT, et al. Carcinoma of the corpus uteri: FIGO $6^{\text {th }}$ annual report on the results of treatment in gynecological cancer. Int J Gynecol Obstet 2006; 95(Suppl 1): 105-43. 